\title{
採卵鷂群における最適更新期の簡易的決定方法に 関する検討
}

\author{
杉本隆重・新部昭夫
}

東京農業大学, 世田谷区 156

\begin{abstract}
大規模な養鵎経営においては，鶏群の更新は単にその一期間が最も高い利益が得られる週齢に行うの ではなく, 長期に渡り更新が何回も繰返されるなかで, 利益が最高になる更新計画を立てることが大切 である。

鷄群の更新に平均利益を最大とする週齢を設定した場合，生産量や卵価あるいは飼料価格の变動が, 利益にどのような影響を及ぼすかの検討を行なった。

週齢による産卵量の累積は 3 次の回帰式で，給飼量の累積は 1 次式で十分近似できた。この条件下で は平均利益を最大とする週の決定に，飼料費や給飼量は無関係であり，育成・廃鷄費や卵価，産卵量が 大きく関与していることが分かった。

更に，平均利益を最大にする更新期を産卵量，卵価，育成・廃鷄費を变数とした重回帰式で求め，こ れを利用して，一般農家であ容易に更新期を決定できることを示した。
\end{abstract}

（家禽会誌， $26 ： 43-52 ， 1989$ )

キーワード : 更新期, 平均利益, 採卵鵎群

採卵経営の大規模化に伴い, 鶏群の更新は, 産卵率, 卵価や飼料費の高低にかかわらず，一定の計画で行なわ なければならない。

更新期の決定は，利益を大きく左右することから，予 め，産卵能力や産卵期間を十分検討したうえで，鵎群の 更新計画をたてることが経営上極めて重要となる。

鶏群の更新は, 単にその一期間が最も高い利益が得ら れる日齢を見付けるのではなく，長期に渡り更新が何回 あ繰返されるなかで，利益が最高になることが必要であ る。

更新期の決定方法に関する検討は, 既にいくつかの報 告 ${ }^{1-21)}$ が見られるが，一般の採卵農家でのそれらの適 用は, 設定条件や計算等が複雑となるため, 未だ更新期 の決定は経験に頼っているのが現状である。

生産設備計画では, 同じ機能を有する設備を類似反復 的に長期に渡って取替え，毎日同じ内容の投資額之報酬 が繰返される場合 (Like-for like Replacement), 利 益を最大にするためには，単位期間当りの平均利益額を 最大にするように更新期を設定することが, 最も経済的 とされている222。

本論は，採卵鵎群の更新に，この設備取り替え問題の 手法を適用した場合，生産量や卵価あるいは飼料価格の

1988 年 3 月 28 日受付
変動が, 利益によ゙の程度の影響を及ぼすかの検討を行な った。

また，週齢による産卵量の累積は，3 次の回帰式で, 給飼量の累積は，1次の回帰式で十分近似でき，この条 件下では, 平均利益を最大とする週の決定に, 飼料費や 給飼量には無関係であることが分かった。

週当りの利益を最大にする更新適期を，産卵量，卵価， 育成費等を变数とした重回帰式を求め，この式を利用す ることによって，各農家でも容易に更新期を決定できる ようにした。適用例を用いて，更新期の決定，更新期ま での産卵量, 飼料消費量, 粗利益を簡単に計算すること ができることを実証的に検討を行なった。

\section{分析材料および方法}

1. 分析材料

分析および回帰式に用いたデー夕は，東北地方で常時 約 9 万羽のシェーバ種を飼養する農家での昭和 57 年か ら昭和 60 年までの経営記録である。

鷄舎は, 単飼で育成から成鷄までの一貫した一棟一群 のロット管理が行なわれ, 飼養羽数, 斃死・淘汰数, 体 重, 産卵量, 破卵, 污卵, 給飼量, 鶏舎内温度等が綿密 に記録されている。

分析に用いた鵎群は，春期（3月〜 5 月）䭒付けの 5 
鶏群 30222 羽, 夏期 (6月～8月) 餉付けの 6 鶏群 30348 羽, 秋期（9 月〜 11 月）餌付けの 7 鶏群 42241 羽, 冬期（12 月～2 月）餉付けの 2 鵎群 18128 羽である。こ れらの鶏群における育成期の体重の変化や育成用飼料の 消費量には季節差があったが，採卵期では，50 週齢以 後の累積産卵量, 破卵量, 減耗摔, 産卵鶏用飼料の消費 量等には差がなかった 23,24$) 。$

分析に用いた採卵期間の平均産卵量と産卵舀用飼料の 給飼量を 5 週齢単位で表 1 に示す。実際の分析では, 1 週齢の単位で行なっている。産卵開始は平均 22.2 週齢 であり，50\% 産卵は平均で 25.3 週齢であった。また, 1 日 1 羽当りの平均産卵量は $46.9 \mathrm{~g}$ であり, 産卵鶏用 飼料の消費量は $106.9 \mathrm{~g}$ であった。また, 以後, 単に 飼料と用いた場合，産卵鶏用の飼料を意味している。

産卵量, 給飼量は, 経過週歯別に, 1 週間 1 羽当りの ヘンハゥス（H. H.）で計算し，年次おょび餌付け月に 対し分散分析の結果, 䭒付け月別の 1 週齢に $5 \%$ 水準で 有意差があるのみで, 以後の週龄では有意差がなかっ た ${ }^{23)}$ 。累積給飼量は，4月の餉付け月に対してのみ有意 差があったが，その他の月では有意差はなかった 次別でも総ての月間で有意差が見られなかった。産卵開 始からの累積給飼量を経過月ごとに比較しても6 ケ月以 後は，その差に有意差が見られなかった ${ }^{23) 。 ま た ， 30 ~}$ 週齿以後の減耗摔も週歯によって有意差が見られず， 70 週齢で平均 $7.08 \pm 0.58 \%$ であった ${ }^{23)}$ 。

2. 最適の定義と利益の定義

鶏卵の収入や飼料費等は, 総て週路単位で計算し, こ こでの利益は, 単に成鵎が成䳕舎に導入されてからオ一 ルアウトされるまでの鷄卵収入と廃鷄代を加算した金額 から，飼料費之育成費を差し引いた金額とする。その利 益金額を成鶏舍編入後の経過週数で割り, 1 週当りの利 益を平均利益と定義した。

\section{平均利益 $=($ 鶏卵収入 - 飼料費 - 育成費 + 廃䳕代 $) /$ （経過週数）}

なお，計算に用いた項目は，総て 1 羽当りに換算した ものであり，便宜上次のとおりとした。

鷄卵収入は，正常の産卵量の累計に産卵期間の平均販 売卵価 $($ 円 $/ \mathrm{kg}$ ) を乗じて計算した。飼料費は，1 日当 りの産卵舀用飼料の消費量に産卵期間の平均購入飼料単 価 (円 $/ \mathrm{kg}$ )を乗じて計算した。育成費は, 初生雊代之 育煼飼料費，施設償却費，光熱費等の育成に係わる費用 の合計とした。廃鷄代は, 通常, 産卵開始から時がたつ につれて安くなるが，更新期付近では，定額とした。

育成費と廃鷄代は定額としているので, 支出となる㕕 成費と収入之なる廃鶏代との差額を，以後，単に育成・ 廃鶏費と呼び，利益の算出や検討にはその值を用いた。

平均利益の算出にあたっては，労働費や光熱費等も重 要な要因となる。これらの值を 1 日 1 羽当りの定額費用 として平均利益の計算式に含めることもできるが， ウイ ンドレスやインライン導入等の飼養形態により, 労働費, 光熱費や滅価償却費は大きく異なってくる。また, 役員 報酬の扱いも農場により違っているのが現状である。

これらのことから, 本研究では, 出来るだけ共通した 項目で，かつ大きなウエイトを占める費用のみを取り上 げ，これらの費用は対象外とした。

平均利益が最大となる值を最大平均利益と以後呼ぶこ とにする。また，平均利益と比較するために用いた最大 累積利益とは，各週ごとの鶏卵収入の累積から育成・廃 鶏費および飼料費の累計を差引いた最大の金額である。

すなわち, 鵎群の繰返し更新を考慮しなければ，最大 累積利益は，一䳕群の産卵期間で得ることができる最も 大きな利益を意味している。

同一生産能力を有する鷄群を繰返し更新することを考 慮すれば，平均利益を最大とする週路で更新することが,

表 1. 1 週 1 羽当りの産卵量抢よび給飼量の基準累積値

'Table 1. Ammounts of egg productions and feed consumptions in a week per hen

\begin{tabular}{|c|c|c|c|c|c|}
\hline $\begin{array}{l}\text { 週 齢 } \\
\text { Age of } \\
\text { weeks }\end{array}$ & $\begin{array}{r}\text { 産卵量 } \\
\text { Production } \\
(\mathrm{g})\end{array}$ & $\begin{array}{c}\text { 給飼量 } \\
\text { Consumption } \\
(\mathrm{g})\end{array}$ & $\begin{array}{l}\text { 週 齢 } \\
\text { Age of } \\
\text { weeks }\end{array}$ & $\begin{array}{c}\text { 産卵量 } \\
\text { Production } \\
\text { (g) }\end{array}$ & $\begin{array}{c}\text { 給飼量 } \\
\text { Consumption } \\
(\mathrm{g})\end{array}$ \\
\hline 21 & 0.0 & 404.0 & 60 & 13554.3 & 30767.8 \\
\hline 25 & 224.9 & 2710.7 & 65 & 15365.8 & 34808.0 \\
\hline 30 & 1917.8 & 6628.6 & 70 & 17113.0 & 38848.7 \\
\hline 35 & 3886.4 & 10664.9 & 75 & 18769.5 & 42856.0 \\
\hline 40 & 5881.0 & 14704.9 & 80 & 20347.6 & 46900.1 \\
\hline 45 & 7846.5 & 18735.2 & 85 & 21756.2 & 50983.7 \\
\hline 50 & 9786.8 & 22726.2 & 90 & 22892.1 & 55033.5 \\
\hline 55 & 11691.9 & 26756.4 & 95. & 23720.1 & 59092.7 \\
\hline
\end{tabular}


全体の利益を最も大きくする ${ }^{22)}$ 。

産卵が開始される週から最大平均利益あるいは最大累 積利益が得られる週でオールアウトするものとし，その 期間を 1 ローテイションと呼ぶ。ローテイションとロー テイションの間は, 通常, 除糞や消毒等に鶏舎を 2 週間 稼働しないものとした。

表 1 に示した週秢に対する産卵量の累計に 3 次の回帰 式 $W(X)$ を適用すると, 式 (1) が得られる。同様に, 飼料給飼量の累計に 1 次の回帰式 $F(X)$ を適用すると, 式 (2) が得られる。両式とも寄与率は，0.999であった。 式中の変数 $X$ は週齢を示し, 式の単位は $\mathrm{kg}$ で与えて いる。

これらの回帰式および式 (5), 式 (6) の重回帰式は, 東 京農業大学の大型コンピュータ FACOM-M 360 とパ ッケージプログラム $\mathrm{SAS}^{25)}$ により，計算をおこなった。 $W(X)=-0.0000248 X^{3}+0.0032989 X^{2}$ $+0.2203403 X-6.6390191 \cdots \cdots \cdots(1)$

$$
\left(R^{2}=0.999\right)
$$

$F(X)=0.7544 X-15.4529 \cdots$

$$
\left(R^{2}=0.999\right)
$$

式 (1), 式 (2) の変数 $X$ は, 0 週龄から適用している が，産卵が始まる週龄 $\mathrm{d}$ を基準にして，式(1), 式 (2) より平均利益を求めると, 式 (3)の $G(X)$ で与えられ る。ただし, 式(1)における 3 次, 2 次, 1 次, 0 次の係 数をそれぞれ $a_{1} \sim a_{4}$ で表わし，式(2)における1 次, 0 次の係数を $b_{1} \sim b_{2}$ とした。また， $K_{1}$ は $X$ 週齢ま での平均卵価であり, $K_{2}$ は $X$ 週噛までの平均飼料単 価, $C$ は 1 羽当りの育成・廃䳕費である。

$$
\begin{aligned}
G(X)= & {\left[K_{1}\left(A_{1} X^{3}+A_{2} X^{2}+A_{3} X+A_{4}\right)\right.} \\
& \left.-K_{2} B_{1} X-C\right] / X \cdots \cdots \ldots \ldots \ldots \ldots \ldots \ldots \ldots \ldots
\end{aligned}
$$

ただし，

$$
\begin{aligned}
& A_{1}=a_{1}, \quad A_{2}=3 a_{1} d+a_{2}, \\
& A_{3}=a_{1}\left(2 d^{2}+d\right)+2 a_{2} d+a_{3}, \\
& A_{4}=a_{1} d^{2}+a_{2} d+a_{3} d+a_{4}, \quad B_{1}=b_{1} .
\end{aligned}
$$

平均利益を最大とする週は, 式 (3) を週龄 $X$ につい て微分して得られる式 (4)の方程式を解くことによって 求めることができる。

$$
\left[K_{1}\left(2 A_{1} X^{3}+A_{2} X^{2}-A_{4}\right)+C\right] / X^{2}=0 \cdots(4)
$$

このように, 産卵量と飼料給飼量が 3 次式と 1 次式で 十分近似でき, 式 (4) で与える平均利益を最大にする週 は, 卵価, 産卵量, および育成・廃鶏費のみの関数とな る。すなわち式 (4) は, 飼料給飼量, 飼料単価之は, 無 関係となる。

式 (4) から, 平均利益の最大週齢は, コンピュータを 利用して数值計算法（例えばニュートンーラプソン法 等 $)^{26)}$ を用いて簡単に解くことができる。この方法は,
単に週ごとの平均利益を計算し，その大小を比較しなが ら最大值を検索するアルゴリズム（以後，単にこの方法 を検索法と呼ぶ）でのコンピュータ利用に比べ，小数点 以下での精度の向上や計算時間の短維等の利点がある。

3. 重回㷌式の適用

コンピュータを利用しない農家でも簡単にこの平均利 益を最大टする週粭が得られれば，便利である。このた め, 卵価 $X_{1}$ (円 $\left./ \mathrm{kg}\right)$ ，表 1 で示した産卵量を基準に, この産卵量に対する適用鷄群の産卵量の割合 (以後, 単 に産卵量の割合と呼ぶ）を $X_{2}$, 育成・廃鶏費を $X_{3}$ (円/羽), 飼料単価を $X_{4}$ (円/ kg), 表 1 で示した給飼 量に対し適用鶏群の給与割合 (以後, 単に給飼量の割合 と呼ぶ）を $X_{5}$ として, 平均利益を最大とする週噛 $Y(X)$ に重回帰式 (5) を適用した ${ }^{25)}$ 。

$$
\begin{aligned}
Y(X)= & 91.3403327-0.0407082 X_{1} \\
& -8.4860029 X_{2}+0.00942523 X_{3} \\
& +0.000491932 X_{4}+0.0168831 X_{5} \cdots(5) \\
& \left(R^{2}=0.967\right)
\end{aligned}
$$

ただし，卵価 $X_{1}$ は， $1 \mathrm{~kg}$ 当り 160 円から 260 円の 実用範囲を 10 円幅で 11 通り変化させた。産卵量の割合 $X_{2}$ は，式 (1) に対し 90\%から $105 \%$ の範囲を $5 \%$ 幅で 4 通りの值である。給飼量の割合 $X_{5}$ は, 式 (2)に対し $80 \%$ から $120 \%$ の範囲を $5 \%$ 幅で 9 通りの值を用意し た。これらの割合は, 式 (1), 式 (2)で与える基準值と異 なった産卵量の鶏群に適用するためである。また, 育成 - 廃鶏費 $X_{3}$ は, 育成費之廃鶏代の差額が, 1 羽当り 600 円から 1200 円の範囲を 100 円幅で, 飼料単価 $X_{4}$ は $1 \mathrm{~kg}$ 当り 22 円から 40 円の奏用範囲を 2 円幅で 10 通りに変化させた。

以上, 式 (5)の重回㷌式は, $X_{1} \sim X_{5}$ の組合せ合計の 27720 通りに対して適用された。この重问帰式は, 全体 の寄与率 $R^{2}$ が 0.967 であった。 $X_{1} \sim X_{5}$ の各寄与率 は, それぞれ $0.295,0.040,0.632,0.000,0.000$ であ った。すなわち, 飼料単俩 $X_{4}$ と給飼量の割合 $X_{5}$ は 寄与率が零であり, 式 (4) で与える微分結果之同様, 平 均利益を最大とする週粭の決定には, 飼料単価と給飼量 は無関係であることが分かる。

ここで, 再度, 式 (5) と同様に, 卵価を $X_{1}$, 産卵量 の割合を $X_{2}$, 育成・廃鶏費を $X_{3}$ として, 平均利益を 最大とする週榆 $y(X)$ の重问㷌式を求め, 式(6)に示 した25)。

$$
\begin{aligned}
y(X)= & 91.3724657-0.0407082 X_{1} \\
-8.4860029 X_{2}+0.00942523 X_{3} & \cdots(6) \\
& \left(R^{2}=0.967\right)
\end{aligned}
$$

$X_{1} \sim X_{3}$ の寄与率は，それぞれ $0.295,0.040,0.632$ であった。 
この重回帰式 (6) を適用した場合, 平均利益を最大と する週の範囲は, 77 週から 89 週であり，平均値は 83.0 週であった。この式による更新週齿と検索法による更新 週齢との差は, 1 週間以内が $97.8 \%, 1$ 週間から 2 週間 以内が $2.2 \%$ であった。この重回帰式 (6)により平均利 益を最大する週齢を求める方法を, 以後, 単に重回帰法 と呼ぶ。

以上の式(1), 式 (2), 式 (6) を用いて, 飼養条件が異な る養鶏農家でも利益を最大にする更新期と 1 羽当りの利 益を次のように計算することができる。

（i）対応鶏群での 1 羽当りの産卵量が表 1 に示さ れた基準産卵量に対する産卵量の割合 $k$ ，育成・廃鶏費 を $c$, 平均卵価 $p$ をそれぞれ算定し，式(6)により平均 利益を最大とする週齢 $y(X)$ を計算する。

（ii）対応鶏群における 1 羽当りの飼料給飼量が表 1 に示される基準消費量に対する割合 $m$ と飼料単価 $s$ を
算定する。週歯 $y(X)$ までの飼料費 $f$ は, 式 $(2)$ より 次式で計算する。

$$
f=s \cdot m \cdot F(y(X))
$$

（iii）週齡 $y(X)$ までの 1 羽当りの産卵量 $w$ は, 式 (1) より次式で計算する。

$$
w=k \cdot W(y(X))
$$

(iv) 1 羽当りの最大平均利益 $Q$ は, 次式で計算す る。

$$
Q=p \cdot w-f+c
$$

\section{結果}

（1）検索法，重回㷌法およびニュートンーラプソン法に より求めた最大平均利益週齡の比較

平均利益を最大とする週齢は，週齢ごとの平均利益を 計算し，その值の大小を比較しながら最大值を求める検 索法，式(4)におけるニュートンーラプソン法を用いた

表 2. 検索法, 重回帰法およびニュートンーラプソン法により求めた最大平均利益週齢の比較

\begin{tabular}{|c|c|c|c|c|c|c|c|c|}
\hline \multirow{2}{*}{$\begin{array}{l}\text { 育成・廃鵎費 } \\
\text { Replacer cost } \\
\text { minus } \\
\text { culled price } \\
\text { (yen) }\end{array}$} & \multirow{2}{*}{$\begin{array}{l}\text { 卵価 } \\
\text { Price } \\
\text { of } \\
\text { egg } \\
\text { (yen) }\end{array}$} & \multirow{2}{*}{$\begin{array}{l}\text { 産卵量の } \\
\text { 割 合 } \\
\text { Produc- } \\
\text { tive } \\
\text { ratio }\end{array}$} & \multirow{2}{*}{$\begin{array}{c}\text { 最大平均 } \\
\text { 利益週歯 } \\
\text { 検索法(A) } \\
\text { Method } \\
\text { of the } \\
\text { search } \\
\text { (A) }\end{array}$} & \multicolumn{2}{|c|}{$\begin{array}{l}\text { Weeks of maximum } \\
\text { average profit }\end{array}$} & \multirow[b]{2}{*}{$|\mathrm{A}-\mathrm{C}| / \mathrm{C}$} & $(\%)$ & Error $(\%)$ \\
\hline & & & & $\begin{array}{l}\text { 重回㷌法(B) } \\
\text { Method of } \\
\text { multiple } \\
\text { regression } \\
\text { (B) }\end{array}$ & $\begin{array}{l}\text { ニュートン- } \\
\text { ラプソン法 }(\mathrm{C}) \\
\text { Method of } \\
\text { Newton- } \\
\text { Raphson }(\mathrm{C})\end{array}$ & & $|\mathrm{B}-\mathrm{C}| / \mathrm{C}$ & $|A-B| / A$ \\
\hline \multirow[t]{3}{*}{1000} & 260 & $\begin{array}{l}0.90 \\
1.05\end{array}$ & $\begin{array}{l}83 \\
81\end{array}$ & $\begin{array}{l}82.6 \\
81.3\end{array}$ & $\begin{array}{l}82.0 \\
82.0\end{array}$ & $\begin{array}{l}1.16 \\
1.28\end{array}$ & $\begin{array}{l}0.64 \\
0.91\end{array}$ & $\begin{array}{l}0.51 \\
0.37\end{array}$ \\
\hline & 210 & $\begin{array}{l}0.90 \\
1.05\end{array}$ & $\begin{array}{l}85 \\
83\end{array}$ & $\begin{array}{l}84.6 \\
83.3\end{array}$ & $\begin{array}{l}83.9 \\
83.9\end{array}$ & $\begin{array}{l}1.29 \\
1.09\end{array}$ & $\begin{array}{l}0.83 \\
0.69\end{array}$ & $\begin{array}{l}0.46 \\
0.41\end{array}$ \\
\hline & 160 & $\begin{array}{l}0.90 \\
1.05\end{array}$ & $\begin{array}{l}87 \\
86\end{array}$ & $\begin{array}{l}86.6 \\
85.4\end{array}$ & $\begin{array}{l}86.9 \\
86.9\end{array}$ & $\begin{array}{l}0.06 \\
1.09\end{array}$ & $\begin{array}{l}0.35 \\
1.81\end{array}$ & $\begin{array}{l}0.41 \\
0.73\end{array}$ \\
\hline \multirow[t]{3}{*}{800} & 260 & $\begin{array}{l}0.90 \\
1.05\end{array}$ & $\begin{array}{l}81 \\
80\end{array}$ & $\begin{array}{l}80.7 \\
79.4\end{array}$ & $\begin{array}{l}80.5 \\
80.5\end{array}$ & $\begin{array}{l}0.65 \\
0.60\end{array}$ & $\begin{array}{l}0.26 \\
1.32\end{array}$ & $\begin{array}{l}0.38 \\
0.73\end{array}$ \\
\hline & 210 & $\begin{array}{l}0.90 \\
1.05\end{array}$ & $\begin{array}{l}83 \\
81\end{array}$ & $\begin{array}{l}82.7 \\
81.5\end{array}$ & $\begin{array}{l}82.0 \\
82.0\end{array}$ & $\begin{array}{l}1.25 \\
1.19\end{array}$ & $\begin{array}{l}0.92 \\
0.63\end{array}$ & $\begin{array}{l}0.33 \\
0.56\end{array}$ \\
\hline & 160 & $\begin{array}{l}0.90 \\
1.05\end{array}$ & $\begin{array}{l}85 \\
84\end{array}$ & $\begin{array}{l}84.8 \\
83.5\end{array}$ & $\begin{array}{l}84.4 \\
84.4\end{array}$ & $\begin{array}{l}0.71 \\
0.47\end{array}$ & $\begin{array}{l}0.43 \\
1.08\end{array}$ & $\begin{array}{l}0.28 \\
1.61\end{array}$ \\
\hline \multirow[t]{4}{*}{600} & 260 & $\begin{array}{l}0.90 \\
1.05\end{array}$ & $\begin{array}{l}79 \\
77\end{array}$ & $\begin{array}{l}78.8 \\
77.5\end{array}$ & $\begin{array}{l}78.9 \\
78.9\end{array}$ & $\begin{array}{l}0.11 \\
2.42\end{array}$ & $\begin{array}{l}0.13 \\
1.75\end{array}$ & $\begin{array}{l}0.25 \\
0.69\end{array}$ \\
\hline & 210 & $\begin{array}{l}0.90 \\
1.05\end{array}$ & $\begin{array}{l}81 \\
80\end{array}$ & $\begin{array}{l}80.8 \\
79.6\end{array}$ & $\begin{array}{l}80.0 \\
80.0\end{array}$ & $\begin{array}{l}1.21 \\
0.04\end{array}$ & $\begin{array}{l}1.01 \\
0.58\end{array}$ & $\begin{array}{l}0.20 \\
0.54\end{array}$ \\
\hline & 160 & $\begin{array}{l}0.90 \\
1.05 \\
\end{array}$ & $\begin{array}{l}82 \\
81 \\
\end{array}$ & $\begin{array}{l}82.9 \\
81.6\end{array}$ & $\begin{array}{l}81.9 \\
81.9\end{array}$ & $\begin{array}{l}0.18 \\
1.04\end{array}$ & $\begin{array}{l}1.25 \\
0.30 \\
\end{array}$ & $\begin{array}{l}1.07 \\
0.75\end{array}$ \\
\hline & & & & & 平籸 & 差 0.88 & 0.83 & 0.52 \\
\hline
\end{tabular}

Table 2. Comparisons of weeks of maximum average profits obtained by the three methods of the search, multiple regression and Newton-Raphson

飼料単価は 30 円 $/ \mathrm{kg}$ ，飼料給飼量は基準值で計算した。

30 yen per $\mathrm{kg}$ for feed price and the standard values of feed consumptions were used in this calculation. 
数值計算法, 式 (6) による重回帰法により求めることが できた。

これらの方法は，平均利益を最大とする週齢を求める 場合，卵価，飼料費，産卵量の割合，育成・廃鷄費の違 いにより，どの程度の差があるかを表 2 に示す。

検索法は, 表 1 に示す週単位のデー夕より平均利益を 計算するため，更新週路は整数值となる。

数値計算法は，表 1 における産卵量之給飼量の累計に 対し，回帰式 (1)，(2) の寄与率 $R^{2}$ が高ければ，それら の式を連続関数とみなして，精度の高い更新週秢を計算 することができる。

数伹計算法として表 2 の計算に用いた二ュートンーラ プソン法は，收束のための初期值を必要とする。更新週 が 75 週齢から 90 週路にあることを考慮して初期値を与 え, 収束の判定範囲が 0.001 以内であれば， 2 回から 3 回の繰返し計算で終了する。このように数值計算法は, 更新週齢までを比較計算する検索法に比べ，計算時間を 大幅に短縮することができる。

式 (6)による重回帰法は，材料および方法で述べたよ うに, 寄与率 $R^{2}$ が 0.967 であり，検索法に比べ $2.2 \%$ の 1 週から 2 週の䛊差を伴う。

検索法 (A) と二ュートンーラプソン法 (C) の䛊差 $(|\mathrm{A}-\mathrm{C}| / \mathrm{C} \times 100)$, 重回帰法 (B) とニュートンーラプ ソン法 $(\mathrm{C})$ の誤差 $(|\mathrm{B}-\mathrm{C}| / \mathrm{C} \times 100)$ と検索法 $(\mathrm{A})$ 之重回帰法（B）の誤差 $(|\mathrm{A}-\mathrm{B}| / \mathrm{A} \times 100)$ を表 2 に示 す。これらの誤差の平均はいずれも $0.9 \%$ 以下であった。 (2) 更新の繰返しによる平均利益と最大累積利益の比較

鶏群の更新を繰返した場合，1回日，3 回日，5 回日 のローテイションにおける最大平均利益と最大累積利益 を比較して表 3 に示す。表 3 に示すように両者の利益は, 飼養期間が異なるので，それぞれの最大利益をそれぞれ の更新週齢で割ることにより 1 週間当りの利益に直して 比較した。また，年間の卵価は，実用的に， $1 \mathrm{~kg}$ 当り 160 円， 200 円， 240 円とし, 飼料単価は, $1 \mathrm{~kg}$ 当り 22 円から 40 円までとした。

この結果, いずれの条件の場合あ最大平均利益は, 最 大累積利益より大きくなる。その差は卵価と飼料単価が 高いほど著しい。飼料単価が $1 \mathrm{~kg}$ 当り 30 円の場合, 卵価が $1 \mathrm{~kg}$ 当り 40 円高くなるに従い, 最大平均利益 は，最大累積利益に比べ約 $0.5 \%$ 大きくなる。卵価が 1 $\mathrm{kg}$ 当り 200 円で両者の利益を比較すると，1 ローテイシ ョン当り最大平均利益は, 最大累積利益に比べ約 $6.9 \%$ 大きな值となる。このことは，3回のローテイションで $20.7 \%, 5$ 回のローテイションで $34.5 \%$ の利益差が両 者間で生ずることになり，最大平均利益での更新が極め て有利であることが分る。
（3）産卵量が最大平均利益と最大累積利益に及ぼす影響 表 1 亿示す産卵量を基準として，90\% から 105\%の 範囲で産卵量が变化したとき, 飼料単価が $1 \mathrm{~kg}$ 当り 22 円から 40 円の範囲で, 最大平均利益之最大累積利益を 比較する。この場合, 前者の方が後者に比べ卵価が 160 円 $/ \mathrm{kg}$ で $4.1 \%$ から $5.7 \%$ 増であり, 卵価が 200 円 $/ \mathrm{kg}$ で $6.5 \%$ から $6.9 \%$ 増, 更に卵価が 240 円 $/ \mathrm{kg}$ では 7.0 \%から $7.6 \%$ 増であった。

このように，産卵量の違いは，両者の卵価が同じとい う条件では，利益差に大きな变化を与えない。また，同 じ産卵量では，卵価が $1 \mathrm{~kg}$ 当り 80 円高くなるに従い, 最大平均利益は最大累積利益に比べ約 $3 \%$ 大きくなった。 両利益に対する飼料費变動の影響を調べると, 卵価が 1 $\mathrm{kg}$ 当り 200 円以上では, 飼料費が $1 \mathrm{~kg}$ 当り 22 円から 40 円の範囲において両利益間の差は平均 $1.0 \%$ 以下と 非常に小さいことが分かった。

\section{考察}

式(6)で提案した重回帰式を，関東地域で 10 万羽を飼 養する農家への適用を行なった。

1 鶏群の導入羽数は, 13024 羽で, 1 日 1 羽当りの産 卵量は $43.0 \mathrm{~g}$ であり, 給飼量は $99.9 \mathrm{~g}$ であった。表 1 に示した基準とする産卵量は 1 日 1 羽当り $46.9 \mathrm{~g}$ であ るから，式(6)に適用する産卵量の割合は，0.92 となる。 また，適用農家での 1 日 1 羽当りの給飼量は $99.9 \mathrm{~g}$, 表 1 に示した基準の飼料量は $106.9 \mathrm{~g}$ であるから，式 (7) に適用する給飼量の割合は，0.93 となる。

育成・廃鶏費を 1 羽当り 1000 円， 800 円と 600 円, 平均卵価を $1 \mathrm{~kg}$ 当り 260 円, 210 円と 160 円に設定し て, 式 (6) の重回帰式より平均利益を最大にする週齢之 式 (7) 式 (9)より, 産卵量, 給飼量および利益を推定し て表 4 に示した。また表 4 に示した観測値とは，式(6) を用いず適用した鷄群の平均利益が最大となる週龄を検 索法で求めたあのであり, 産卵量, 給飼量および利益も その週齢までの実際の值を用いて計算した。

両方法による計算值を比較すると, 最大平均利益の週 齢は, 平均 0.5 週の誤差であり, 利益では平均 $0.79 \%$, 産卵量では平均 $0.63 \%$, 給飼量では平均 $0.80 \%$ の䛊差 であった。

本計算では，その鷄群における産卵量と給飼量を先に 求めておいて, 重回帰式に適用したので誤差は大変小さ くなったが，実際の適用にあたっては，過去の実績デー 夕を用いて，䳕群の能力を推定することになる。適用農 家での過去の平均産卵量は $42 \mathrm{~g} /$ 羽・日であり, 給飼量 は，平均 $101 \mathrm{~g} /$ 羽・日であった。これらの平均值を用 いて，先の鶏群における利益を推定すると，尖際の值を 
表 3. 最大平均利益と最大累積利益

Table 3. Influence of prices of egg and feed for maximum

\begin{tabular}{|c|c|c|c|c|c|c|c|c|}
\hline \multirow{2}{*}{$\begin{array}{l}\text { 㧮 価 } \\
\text { Price } \\
\text { of } \\
\text { egg } \\
\text { (yen/kg) }\end{array}$} & \multirow{2}{*}{$\begin{array}{c}\left.\text { 利益/週 }{ }^{1}\right) \\
\text { Profit } \\
\text { per } \\
\text { week } \\
\text { (yen) }\end{array}$} & \multirow{2}{*}{$\begin{array}{c}\text { ローテイション } \\
\text { Rotation } \\
\text { 飼料単価 (円/kg) } \\
\text { Price of feed } \\
\text { (yen/kg) }\end{array}$} & \multicolumn{6}{|c|}{$\begin{array}{l}\text { 第 } 1 \text { 回 } \\
\text { First rotation }\end{array}$} \\
\hline & & & 22 & 26 & 30 & 34 & 38 & 40 \\
\hline \multirow{3}{*}{160} & $\begin{array}{c}\text { 最大平均利益 } \\
\text { Max. Ave. profit }\end{array}$ & & 22.1 & 19.1 & 16.1 & 13.1 & 10.2 & 8.7 \\
\hline & $\begin{array}{l}\text { 最大累積利益 } \\
\text { Max. cumulat. profit }\end{array}$ & & 20.7 & 18.0 & 15.2 & 12.4 & 9.8 & 8.4 \\
\hline & $\begin{array}{c}\text { 堌減率 }{ }^{2)} \\
\text { Difference }(\%)\end{array}$ & & 6.3 & 5.8 & 5.6 & 5.3 & 3.9 & 3.4 \\
\hline \multirow{3}{*}{200} & $\begin{array}{l}\text { 最大平均利益 } \\
\text { Max. Ave. profit }\end{array}$ & & 34.9 & 31.9 & 28.9 & 26.0 & 23.0 & 21.5 \\
\hline & $\begin{array}{l}\text { 最大累積利益 } \\
\text { Max. cumulat. profit }\end{array}$ & & 32.7 & 29.7 & 27.1 & 24.1 & 21.4 & 19.9 \\
\hline & $\begin{array}{l}\text { 増減率 } \\
\text { Difference (\%) }\end{array}$ & & 6.3 & 6.9 & 6.2 & 7.3 & 7.0 & 7.4 \\
\hline \multirow{3}{*}{240} & $\begin{array}{l}\text { 最大平均利益 } \\
\text { Max. Ave. profit }\end{array}$ & & 47.8 & 44.8 & 41.8 & 38.8 & 35.8 & 34.4 \\
\hline & $\begin{array}{l}\text { 最大累積利益 } \\
\text { Max. cumulat. profit }\end{array}$ & & 44.6 & 41.6 & 38.6 & 35.7 & 33.1 & 31.6 \\
\hline & $\begin{array}{l}\text { 増減率 } \\
\text { Difference（\%) }\end{array}$ & & 6.7 & 7.1 & 7.7 & 8.0 & 7.5 & 8.1 \\
\hline \multicolumn{2}{|c|}{$\begin{array}{l}\text { 増減率の平均値 } \\
\text { Average of difference }(\%)\end{array}$} & & 6.43 & 6.60 & 6.50 & 6.87 & 6.13 & 6.30 \\
\hline
\end{tabular}

1) 利益は, 育成・廃鶏費を 800 円として計算した。

Profit was calculated with the value of 800 yen which of the cost for replacer minus price

2) 增減率: (平均利益一最大利益) / 平均利益 $\times 100$.

Difference : (Average profit-Maximum profit)/Average profit $\times 100$.

用いた場合に比べその誤差は 7\% 以下, 産卵量, 給飼量 の推定誤差は約 $2 \%$ 以下であり，十分適用可能である。

このように，式(6)で提案した重回帰式を用いて個別 農家に適用するには，その農家での産卵量, 育成費, 廃 鷄代，卵価等を過去の実績值から推定しなければならな い。

一般には，廃鷄代は年ごとでの変動は極めて小さく， 確実に推定できる要因と言ってよい。育成費は, 飼料価 格, 光熱費等の変動費が大幅に变動しないかぎり, 变化 はあまりないが，オールアウト週㱓の決定には大きな影 響を及ぼす要因と言ってよい。鷄種や餉付け季節によっ て産卵量, 飼料消費量の違いのある農家は, 鶏群の更新 ごとに設定値を変える必要がある。

最も推定が困難な要因が卯価である。昭和 57 年から 昭和 61 年の過去 5 年間の平均卵価は, 最低値の年で 238.2 月 $/ \mathrm{kg}$ であり, 最高值の年で 265.5 円 $/ \mathrm{kg}$ であ った。その差は 27.3 円 $/ \mathrm{kg}$ である。飼料費を $1 \mathrm{~kg}$ 当 り 30 円，育成・廃鵎費を 800 円/羽とし，産卵量を表
1 に示す基準值とすれば，平均利益を最大にするオール アウト週齢は, 最低值の卵価 238.2 円 $/ \mathrm{kg}$ で 80.7 週齢, 最高值 265.5 円 $/ \mathrm{kg}$ で 79.6 週龄となる。このとき, そ れぞれの利益差は，後者の方が約 15\% 高となる。

卵価は，需要と供給の関係で決まると言ってよい。た とえ，短期的にコンピュータ等で卵価変動を予測できた としても, 多くの養鷄家が高值に合せて産卵を調節すれ ば生産過剩となり, 卵価は暴落する。逆に, 低卵価に合 せて生産を調節すれば, 品不足で卵価は高騰することに なる。

いずれにしても, 経営の大規模化が進み, 卵価の安值 安定が続く情況では, 予測による夕イムリな生産出荷よ り, むしろ長期安定の生産技術体系の確立と計画生産に よる出荷が望まれる。その中で, 利益に大きな影響を与 える鶏群の更新問題は極めて大切となる。本論では, 更 新期を決定するうえで，簡易的ではあるが，実用的な手 法の提案を行なった。今後, 更に育成・廃鶏費, 卵価, 産卵量, 飼料量の増減が, 平均利益にどのような影響を 
に対する卵価および飼料単価の影響

average profits and maximum cumulative profits

\begin{tabular}{|c|c|c|c|c|c|c|c|c|c|c|c|c|}
\hline \multicolumn{6}{|c|}{$\begin{array}{c}\text { 第 } 3 \text { 回 } \\
\text { Third rotation }\end{array}$} & \multicolumn{6}{|c|}{$\begin{array}{l}\text { 第 } 5 \text { 回 } \\
\text { Fifth rotation }\end{array}$} & \multirow{2}{*}{$\begin{array}{c}\text { 平均 } \\
\text { Average }\end{array}$} \\
\hline 22 & 26 & 30 & 34 & 38 & 40 & 22 & 26 & 30 & 34 & 38 & 40 & \\
\hline 21.8 & 18.8 & 15.9 & 12.9 & 10.0 & 8.5 & 21.6 & 18.7 & 15.8 & 12.9 & 9.9 & 8.5 & 14.9 \\
\hline 20.4 & 17.7 & 15.0 & 12.2 & 9.6 & 8.2 & 20.3 & 17.6 & 14.9 & 12.2 & 9.5 & 8.2 & 14.1 \\
\hline 6.4 & 5.9 & 5.7 & 5.4 & 4.0 & 3.5 & 6.0 & 5.9 & 5.7 & 5.4 & 4.0 & 3.5 & 5.1 \\
\hline 34.4 & 31.4 & 28.5 & 25.5 & 22.6 & 21.1 & 34.2 & 31.2 & 28.3 & 25.4 & 22.5 & 21.0 & 27.7 \\
\hline 32.1 & 29.2 & 26.6 & 23.6 & 21.0 & 19.6 & 32.0 & 29.1 & 26.5 & 23.6 & 20.9 & 19.5 & 25.8 \\
\hline 6.7 & 7.0 & 6.7 & 7.5 & 7.1 & 7.1 & 6.4 & 6.7 & 6.4 & 7.1 & 7.1 & 7.1 & 6.9 \\
\hline 47.0 & 44.1 & 41.2 & 38.2 & 35.3 & 33.8 & 46.7 & 43.8 & 40.9 & 38.0 & 35.0 & 33.6 & 40.6 \\
\hline 43.8 & 40.9 & 38.0 & 35.0 & 32.5 & 31.1 & 43.7 & 40.8 & 37.8 & 34.9 & 32.4 & 31.0 & 37.5 \\
\hline 6.8 & 7.3 & 7.8 & 8.4 & 7.9 & 8.0 & 6.4 & 6.8 & 7.6 & 8.2 & 7.4 & 7.7 & 7.5 \\
\hline 6.63 & 6.73 & 6.73 & 7.10 & 6.33 & 6.20 & 6.27 & 6.47 & 6.57 & 6.90 & 6.63 & 6.27 & 6.50 \\
\hline
\end{tabular}

of culled chicken

及ぼすかの詳細で定量的な検討をする必要がある。この ことは，鶏群更新の決定のみならず，採卵経営全体に有 用である。また本論で取り上げなかった，強制換羽を用 いた生産での更新期の決定方法についても，次问に報告 する予定である。

\section{文献}

1）海老沢昭二・山下近男・冨塚武男・山西 清・高 橋 仁（1975）卵用鷂の産卵期における制限給飼 の影響, 家禽会誌, $12: 28-36$.

2) Gowe, R.S., J.H. Strain, R.D. Crawford, A.T. Hill, S.B. Slen and W.F. Mountain (1965) Restricted feeding of growing pullets. I. The effect on the performance traits of egg production stock, Poult. Sci., 44: 717-726.

3) Hollands, K.G. and R.S. Gowe (1965) The economic value of restricted and fullfeeding during confinement rearing on two-year egg production, Brit. Poult. Sci.,
6 : 287-295.

4) Fulder, H.L. and W.S. Dunahod (1962) Restricted feeding of pullets. 2. Effect of duration and time restriction on threeyear laying house performance, Poult. Sci., 41 : 1306-1314.

5）柏木 忍・白崎克治・中曾博之・貝榢隆艤・川尾 春行・高橋靖生・松崎止治・池田公良・奥川址孝 （1978）採卵鷄の経済寿命延長のための飼養技術. 育成飼料給与法㧍よび産卵制御日齢の影響, 家禽 会誌, $15: 120-128$.

6）柏木 忍・白崎克治・貝榢隆義・中曾博之・竖瀨 伸夫・山尾春行・高橋靖生・松崎止治・池田公良 ・奥山此孝（1981）採卵鶏の経済寿命延長のため の飼養技術. 第 3 報 育成期および成䳕期を通じ た飼養技術の検討，家禽会誌，18：67-77.

7）柏木 忍・白崎克治・相良博信・貝㴚隆義・中曾 博之・岩瀨伸夫・山尾春行・高橋靖生・松崎止治 - 池田公良・奥山正孝（1981）採卵鷄の経済寿命 延長のための飼養技術．第 4 報 一連の飼養技術 に扔ける経済性と経済的飼育期間の検討，咨禽会 
表 4. 簡易的更新期

Table 4. An application of the simplified

\begin{tabular}{|c|c|c|c|c|c|c|}
\hline \multirow{2}{*}{$\begin{array}{c}\text { 育成 } \cdot \text { 廃鵎費 } \\
\text { Replacer cost } \\
\text { minus } \\
\text { culled price } \\
\text { (yen) }\end{array}$} & \multirow{2}{*}{$\begin{array}{l}\text { 卵 価 } \\
\text { Price } \\
\text { of } \\
\text { egg } \\
\text { (yen) }\end{array}$} & \multicolumn{2}{|c|}{$\begin{array}{l}\text { 最大平均利益週齢 } \\
\text { Weeks of maximum } \\
\text { average profit }\end{array}$} & \multicolumn{3}{|c|}{$\begin{array}{l}\text { 利 益 (円) } \\
\text { Profit (yen) }\end{array}$} \\
\hline & & $\begin{array}{c}\text { 推定値 } \\
\text { Estimate }\end{array}$ & $\begin{array}{l}\text { 観測值 } \\
\text { Actual }\end{array}$ & $\begin{array}{l}\text { 推定值 } \\
\text { Estimate }\end{array}$ & $\begin{array}{l}\text { 観測值 } \\
\text { Actual }\end{array}$ & $\begin{array}{l}\text { 誤 }{ }^{\text {差 }}(2) \\
\text { Error }(\%)\end{array}$ \\
\hline \multirow{3}{*}{1000} & 260 & 83 & 82 & $\begin{array}{l}2485.5 \\
(100.0)^{3)}\end{array}$ & $\begin{array}{l}2473.2 \\
(100.0)\end{array}$ & 0.50 \\
\hline & 210 & 85 & 85 & $\left(\begin{array}{l}1621.1 \\
(-34.8)^{3)}\end{array}\right.$ & $\begin{array}{c}1636.7 \\
(-33.8)\end{array}$ & 0.95 \\
\hline & 160 & 87 & 87 & $\begin{array}{c}705.8 \\
(-71.6)^{3)}\end{array}$ & $\begin{array}{c}709.8 \\
(-71.3)\end{array}$ & 0.56 \\
\hline \multirow{3}{*}{800} & 260 & 81 & 81 & $\begin{array}{l}2606.3 \\
(100.0)\end{array}$ & $\begin{array}{l}2631.7 \\
(100.0)\end{array}$ & 0.97 \\
\hline & 210 & 83 & 82 & $\begin{array}{l}1769.0 \\
(-32.1)\end{array}$ & $\begin{array}{l}1756.6 \\
(-33.3)\end{array}$ & 0.71 \\
\hline & 160 & 85 & 85 & $\begin{array}{c}879.0 \\
(-66.3)\end{array}$ & $\begin{array}{c}886.0 \\
(-66.3)\end{array}$ & 0.79 \\
\hline \multirow{3}{*}{600} & 260 & 79 & 78 & $\begin{array}{l}2722.5 \\
(100.0)\end{array}$ & $\begin{array}{l}2695.2 \\
(100.0)\end{array}$ & 1.01 \\
\hline & 210 & 81 & 81 & $\begin{array}{l}1913.0 \\
(-29.7)\end{array}$ & $\begin{array}{c}1927.1 \\
(-28.5)\end{array}$ & 0.73 \\
\hline & 160 & 83 & 82 & $\begin{array}{l}1048.9 \\
(-61.5)\end{array}$ & $\begin{array}{l}1039.9 \\
(-61.4)\end{array}$ & 0.87 \\
\hline
\end{tabular}

䛊差の平均値 Average of error

0.79

1) 適用条件：飼料単価 30 円 $/ \mathrm{kg}$, 表 1 に示した基準値に対する産卵量の割合 0.92 , 基準値に対する飼料給飼量 Applied conditions: price of feed 30 yen $/ \mathrm{kg}$, productive ratio for criteion 0.92 , feed consump-

2) 誤差: | 推定值 - 観測值 | / 観測值 $\times 100$.

Error : | Estimate-Actual | / Actual $\times 100$.

3)（）内は, 卵価 260 円/kg のときの利益に対する増減の割合をパーセントで示している。

Value in the parenthesis indicates the percent of difference for the profit obtained in the price

誌, $18: 105-119$.

8）目加田博行・梅田 勲・内藤二郎・細川 明・冨 塚武男・竹下雅文（1979）産卵彩鳥の経済性に対す る産卵調整の検討, 家离会誌, $16: 215-222$.

9）中沢 稔・吉田賢治・北野良一（1968）強制換羽 が産卵鶏におよぼす影響. I . 春季に換羽を誘起 した場合, 家禽会誌, $5:$ 131-135.

10）中沢 稔・古田賢治・冨塚武男・下司 一（1970） 強制換羽が産卵彩におよぼす影㗽。【、秋季に換 羽を誘起した場合，家禽会誌，7:12-17.

11) Noles, R.K. (1966) Subsequent production and egg quality of forced molted hens, Poult. Sci., 45 : 50-57.

12）坂井田節・杉山正義・金原弘志・赤間栄蔵・塩谷 栗夫（1976）鶏の制限給飼に関する研究，I，採 卵用鶏種に対する産卵期間中の制限給飼, 家离会 誌, $13: 235-242$.

13）白崎克治・柏木 忍・貝塚隆義 - 中曾博之・岩瀬 伸夫・山尾春行・高橋靖生・松崎正治（1981）採 卵彩鳥の経済寿命延長のための飼養技術. 育成飼料
給与法および産卵制御日齢の影響，家禽会誌， 17 : 184-192.

14）白崎克治・柏木 忍（1987）採卵䊿の経済寿命延 長のための飼養技術. 第 5 報 卵価, 飼料価格の 変動が飼育タイプの収益と最適飼育期間に及ぼす 影響, 一卵価之飼料価格の関係から設定された価 格一，家禽会誌，24:244-252.

15）白崎克治・柏木 忍（1987）採卵鶏の経済寿命延 長のための飼養技術. 第 6 報 卵価, 飼料価格の 変動が飼育夕イプの収益と最適飼育期間に及ぼす 影響，一実勢による価格設定一，家禽会誌，24： 336-347.

16）鈴木邦彦・大須賀章高（1984）採卵鶏群の更新適 期決定手法の検討, 愛知農総試研報, 16:456459.

17) Wilson, H.R., J.L. Fry, R.H. HARMS and L.R. ArRington (1967) Performance of hens molted by various methods, Poult, Sci., 46 : 1406-1412.

18）吉田 実（1971）鶏に対する栄養素給与量の制限, 
決定方法の適用結果 ${ }^{11}$

method to a single poultry farm

\begin{tabular}{|c|c|c|c|c|c|}
\hline \multicolumn{3}{|c|}{$\begin{array}{l}\text { 産卵量 (kg) } \\
\text { Egg yield (kg) }\end{array}$} & \multicolumn{3}{|c|}{$\begin{array}{c}\text { 飼料給飼量 (kg) } \\
\text { Feed consumption (kg) }\end{array}$} \\
\hline $\begin{array}{l}\text { 推定値 } \\
\text { Estimate }\end{array}$ & $\begin{array}{l}\text { 観湘値 } \\
\text { Actual }\end{array}$ & $\begin{array}{l}\text { 誤 差 } \\
\text { Error }(\%)\end{array}$ & $\begin{array}{l}\text { 推定值 } \\
\text { Estimate }\end{array}$ & $\begin{array}{l}\text { 観測値 } \\
\text { Actual }\end{array}$ & $\begin{array}{l}\text { 誝 差 } \\
\text { Error }(\%)\end{array}$ \\
\hline $\begin{array}{c}18.4 \\
(100.0)\end{array}$ & $\begin{array}{c}18.4 \\
(100.0)\end{array}$ & 0.45 & $\begin{array}{c}43.4 \\
(100.0)\end{array}$ & $\begin{array}{c}43.1 \\
(100.0)\end{array}$ & 0.72 \\
\hline $\begin{array}{l}18.9 \\
(2.6)\end{array}$ & $\begin{array}{l}19.0 \\
(3.7)\end{array}$ & 0.66 & $\begin{array}{l}44.9 \\
(3.3)\end{array}$ & $\begin{array}{l}45.2 \\
(4.9)\end{array}$ & 0.79 \\
\hline $\begin{array}{l}19.3 \\
(5.0) \\
\end{array}$ & $\begin{array}{l}19.4 \\
(5.9) \\
\end{array}$ & 0.42 & $\begin{array}{l}46.3 \\
(6.6) \\
\end{array}$ & $\begin{array}{l}46.6 \\
(8.0) \\
\end{array}$ & 0.65 \\
\hline $\begin{array}{c}18.0 \\
(100.0)\end{array}$ & $\begin{array}{c}18.1 \\
(100.0)\end{array}$ & 0.74 & $\begin{array}{c}42.1 \\
(100.0)\end{array}$ & $\begin{array}{c}42.4 \\
(100.0)\end{array}$ & 0.74 \\
\hline $\begin{array}{l}18.5 \\
(2.7)\end{array}$ & $\begin{array}{l}18.3 \\
(1.3)\end{array}$ & 0.64 & $\begin{array}{l}43.5 \\
(3.4)\end{array}$ & $\begin{array}{l}43.1 \\
(1.7)\end{array}$ & 0.96 \\
\hline $\begin{array}{l}18.9 \\
(5.4)\end{array}$ & $\begin{array}{l}19.0 \\
(5.1)\end{array}$ & 0.48 & $\begin{array}{l}45.0 \\
(6.8)\end{array}$ & $\begin{array}{l}45.2 \\
(6.6)\end{array}$ & 0.55 \\
\hline $\begin{array}{c}17.5 \\
(100.0)\end{array}$ & $\begin{array}{c}17.3 \\
(100.0)\end{array}$ & 0.90 & $\begin{array}{c}40.8 \\
(100.0)\end{array}$ & $\begin{array}{c}40.3 \\
(100.0)\end{array}$ & 1.09 \\
\hline $\begin{array}{l}18.0 \\
(2.9)\end{array}$ & $\begin{array}{l}18.1 \\
(4.4)\end{array}$ & 0.54 & $\begin{array}{l}42.2 \\
(3.5)\end{array}$ & $\begin{array}{l}42.4 \\
(5.2)\end{array}$ & 0.49 \\
\hline \multirow[t]{2}{*}{$\begin{array}{l}18.5 \\
(5.7)\end{array}$} & $\begin{array}{l}18.3 \\
(5.8) \\
\end{array}$ & 0.84 & $\begin{array}{l}43.6 \\
(7.0) \\
\end{array}$ & $\begin{array}{l}43.1 \\
(6.9) \\
\end{array}$ & 1.21 \\
\hline & & 0.63 & & & 0.80 \\
\hline
\end{tabular}

の割合 0.93 .

tion ratio for criterion 0.93

of egg 260 yen $/ \mathrm{kg}$.

家禽会誌, $8: 131-143$.

19）吉田 実（1980）採卵鶏の飼養技術体系とそのと きの最適更新時期 (1), 畜産の研究, $34: 3-7$.

20）吉田 実（1980）採卵彩の飼養技術体系とそのと きの最適更新時期 (2), 畜産の研究，34:252254.

21) Sugimoto, T., A. Nibe and K. Kumagai (1987) A method of prediction for egg production using computer simulation system, Jpn. J. Zootech. Sci., 57 : 737-746.

22）千住鎮雄 - 伏見多美雄，設備投資計画法. 日科技
連. 東京. 1974.

23）新部昭夫・杉本隆重・石岡宏司（1987）採卵鶏の 季節別発育成績と産卵成績に関する検討, 日本畜 産学会第 78 回大会. 要旨 p. 47.

24）杉本隆重・新部昭夫・長谷川俊一（1987）採卵鶏 群における更新期の簡易的な決定方法に関する検 討, 日本畜産学会第 79 回大会. 要旨 p. 61 .

25) SAS USER'S GUIDE : Statistics V 5 (1985), SAS Institute Inc., Cary NC.

26）礒野和男・大野 豊, FORTRAN による数值 計算ハンドブック.オーム社. 東京. 1978. 


\title{
A Simplified Method to Optimaize the Keeping Period in Layer Flock
}

\author{
Takashige Sugimoto and Akio Nibe \\ Tokyo University of Agriculture, Setagaya-ku 156
}

In deciding the keeping period in layers reared in the large scale farm, it is important to maximize the economic profits by doing the several rotations of layer flocks within a certain term, but not by one rotation of a layer flock at the age of weeks which show the most maximum profit only.

This paper deals with the influences of egg production, price of egg and price of feed on the economic profits, which were closely connected with the age of weeks of the maximum average profit. Numbers of management records of layers used in this study were 120939 of Shaver obtained from a single farm in TOHOKU area during from 1982 to 1985.

The cumulative egg productions by week were enough approximated with a cubic curve of a regression expression, and also the cumulative feeds were with a linear. In these conditions, raising cost, price of egg and egg production were greatly connected with the weeks of maximum average profit, but no influences of feed consumption or price of feed.

For deciding the weeks for maximum average profit, a numerical expression was drawn by the method of multiple regression with three variables of egg production, price of egg and raising cost and was tested. As the results, it was proved that this expression was very effective in making dicision on the keeping period for poulty farmers.

(Jpn. Poult. Sci., $26: 43-52,1989$ )

Key words : Keeping period, Average profit, Layer flock 